2. Словарь прикладной интернетики под. ред. С.А. Нехаева, Н.В. Кривошеина [Электронный pecypc] // PERFEKT.RU: словари, глоссарии, справочники, энциклопедии онлайн. - Режим доступа: http://www.perfekt.ru/dictionaries/netica.html.

3. ICT Facts and Figures 2016: report on 14th World Telecommunication/ICT Indicators Symposium (WTIS) [Текст], 21-23 November, Botswana, 2016. - 8 p.

4. Sweeney S. 101 ways to promote your tourism web site: filled with proven internet marketing tips, tools. [Текст] // Maximum Press, 2008. - 391 p.

5. The Statistics Portal [Электронный ресурс] // Statistics and facts about social media usage. - Режим доступа: https://www.statista.com/topics/1164/social-networks.

\title{
Юридические курсы как один из способов повышения правовой грамотности населения Нерюнгринского района
}

\author{
Кирикова Е.Н., студентка, \\ Нерюнгринский филиал \\ ГАПОУ РС (Я) «Алданский политехнический техникум», \\ 2. Нерюнгри \\ E-mail: kirikova1995@mai.ru
}

Научный руководитель: Чекалина Т.Н.

Каждый из нас, на протяжении жизни, постоянно сталкивается с вопросами юридического характера - заполнение бланков, заключение договоров, оформление завещания, наследства, расторжение брака и др. Но даже эти, казалось бы, повседневные вопросы, способны озадачить. А как часто люди страдают из-за правовой неграмотности? Приведу несколько случаев:

1. Информационный сайт г. Нерюнгри в материале «В г. Нерюнгри женщина попалась на уловку телефонных мошенников» (01.11.2016) сообщает, что у гражданки 1983 года рождения сняли с карты 48000 рублей. Она разместила объявление о продаже квартиры на Авито, и сообщила номер своей банковской карты потенциальному покупателю. После кражи денег мошенник перестал выходить на связь, гражданка обратилась в полицию. ${ }^{1}$

2. На сайте газеты «Индустрия Севера» был опубликован материал «Опять мошенники»(8.04.2016), в котором сообщалось, что 29 марта неизвестная женщина пришла в квартиру к гражданину 1934 года рождения, инвалиду по зрению, представилась старой знакомой и предложила помочь по хозяйству. Пенсионер беспрепятственно впустил «помощницу» в квартиру, так как она показалась ему знакомой. После ее визита мужчина обнаружил пропажу денежной суммы в размере 109000 рублей и обратился в полицию. ${ }^{2}$

\footnotetext{
${ }^{1}$ Информационный сайт г.Нерюнгри. Новостной материал: «В г.Нерюнгри женщина попалась на уловку телефонных мошенников» [Электронный ресурс] URL: http://nerungri.ru/news/orgs/16810

${ }^{2}$ Индустрия Севера. Новостной материал: «Опять мошенники» [Электронный ресурс] URL: http://www.indsever.ru/?module=articles\&action=view\&id=4102
} 
Данные инциденты показывают, что из-за юридической неграмотности страдают многие жители нашего региона, независимо от возраста, образования и социального положения.

Так что же такое юридическая грамотность? Юридическая грамотность - это правовая культура человека, хорошее знание своих прав и обязанностей и нормативноправовых актов, регулирующих отношения между людьми, социальными общностями, организациями; умение применять правовые знания при анализе конфликтных ситуаций, давать правовую оценку действиям социальных субъектов. ${ }^{3}$

Тема актуальна в связи с низкой правовой грамотностью населения. Не у всех есть время, средства и желание получать юридическое образование, а самостоятельного изучения законов не всегда достаточно. Приведенные выше случаи подтверждают несмотря на наличие большого количества доступной юридической информации, люди не знают, как правильно её использовать.

Объект работы - юридическая неграмотность населения Нерюнгринского района.

Предмет работы - бесплатные юридические курсы и консультации как способ повышения правовой грамотности населения Нерюнгринского района.

Основу методологии исследований составляют эмпирические методы - опрос, моделирование, контент-анализ, наблюдение; и теоретические - традуктивное умозаключение.

Теоретическая значимость работы заключается в дальнейшем исследовании способов повышения юридической грамотности населения.

Практическая значимость работы. Собранные и проанализированные в ходе нашего исследования данные, а также полученные выводы могут использоваться в юридической практике и применяться в преподавании таких юридических дисциплин, как «Конституционное право», «Документационное обеспечение управления» и т.д.

Цель работы - исследовать необходимость проведения бесплатных юридических курсов и консультаций и организовать их проведение.

Для достижения цели необходимо выполнить следующие задачи:

1. Провести опрос среди жителей Нерюнгринского района, чтобы выявить, будут ли востребованы такие занятия, и какая информация окажется наиболее актуальной и полезной.

2. Проанализировать действующие программы, направленные на повышение юридической грамотности в Нерюнгринском районе.

3. Определить потенциально-значимые темы, которые будут изучаться на юридических курсах.

4. Найти потенциальные места проведения и источники финансирования юридических курсов.

\section{1 Опрос.}

Для того, чтобы узнать, действительно ли необходимы предлагаемые в данной работе юридические курсы, был проведен опрос среди жителей Нерюнгринского района. Интервьюируемыми стали 67 человек в возрасте от 20 до 70 лет. Из них 45\% обращались к юристам 1-5 раз в жизни, по таким вопросам, как: исковое заявление в суд, страхование, переоформление недвижимости, трудовые споры, заключение договора, оформление наследства, 37\% опрошенных обращаются к юристам ежегодно.

\footnotetext{
${ }^{3}$ Национальная педагогическая энциклопедия [Электронный ресурc] URL: http://didacts.ru/termin/yuridicheskaja-gramotnost.html
} 
Их интересуют вопросы, также связанные со страхованием, заключением договоров, алиментами. 18\% утверждают, что ни разу не обращались к юристам. Тем не менее, 100 \% опрошенных ответили, что нуждаются в бесплатных юридических курсах.

2 Анализ программ, проводимых для повышения правовой культуры населения в Нерюнгринском районе.

Нерюнгринская районная администрация на протяжении нескольких лет проводила различные мероприятия, направленные на рост юридической грамотности населения:

- организация дней бесплатной юридической помощи;

- правовое просвещение населения в местных СМИ;

- проведение ежегодного конкурса «Лучший юрист Нерюнгринского района»;

- правовое воспитание школьников и студентов;

- развитие Центров правовой информации на базе муниципальных библиотек Нерюнгринского района;

Эти и другие мероприятия были включены в постановление Нерюнгринской районной администрации от 03.09.2012г № 1739 «Об утверждении плана основных мероприятий по повышению правовой культуры населения муниципального образования «Нерюнгринский район» на 2012-2016 годы». Постановление пытались продлить на 2017-2021 годы, но из-за недостатка финансирования программа не была утверждена. Тем не менее, она доказала востребованность правовой информации среди населения нашего района.

На базе Нерюнгринской городской библиотеки с 2000 года работает Центр правовой и деловой информации, который предоставляет всем желающим правовую информацию с помощью справочно-поисковых систем Консультант ПЛЮС и ГАРАНТ, а также в печатных вариантах. Ежемесячно ЦПДИ проводит конкурсы, встречи, направленные на правовое просвещение населения. Например, в феврале проходили тематическая беседа «Взятка-элемент коррупции» и конкурс «Я голосую за своё будущее». Помимо этого, ЦПДИ приглашает к сотрудничеству юристов, судебных приставов, миграционную службу, роспотребнадзор и др. для оказания необходимой консультации жителям Нерюнгринского района. По статистике, за 2016 год в ЦПДИ обратилось 7666 человек, причем, количество желающих повысить свою правовую грамотность с каждым годом растет.

\section{3 Потенциальные темы для бесплатных юридических курсов.}

Мероприятия, проводимые администрацией и Центром правовой и деловой информации, создали хорошую теоретическую базу, а предлагаемые мной курсы возможность научить жителей нашего района правильно использовать юридические данные на практике. Примерная программа курсов:

5. Правильное заполнение документов.

Получение паспорта, перерегистрация, устройство на работу, увольнение, составление доверенности или завещания - все это сопровождается множеством бумаг, оформлением которых мало кто любит заниматься. Данные занятия научат правильной работе с документами и избавят от страха ошибки при заполнении бланков.

6. Изучение и подписание договора.

Всем известно о том, что перед подписанием договора его необходимо изучить. Все слышали о мелком шрифте. Но мало кто знает, как правильно читать договор, где именно стоит искать подвох, и на что нужно обращать особое внимание. 
3. Треть опрошенных ответили, что их знакомые не раз попадались на уловки мошенников. Курсы научат, как не стать жертвой аферистов и отличить подлинный документ от фальшивого.

4. Каждый месяц люди платят за услуги ЖКХ, и у многих возникают вопросы за что я плачу? На этих занятиях научат, как читать квитанции ЖКХ, расскажут, к кому обратиться, если возникли какие-либо проблемы в этой сфере. 98\% процентов интервьюируемых хотели бы ознакомиться с данной темой на курсах.

Перечень можно дополнять другими, актуальными для жителей Нерюнгринского района, вопросами.

\section{4 Потенциальные места проведения и источники финансирования юридических курсов.}

Курсы лучше проводить в небольших группах по 5-7 человек. «Малая группа» это практически не меняющаяся по составу группа обучающихся, находящихся в постоянном взаимодействии друг с другом. ${ }^{4}$

В.К. Дьяченко, Ю.В. Василькова, О.Г. Ким и другие исследователи считают, что малая группа является продуктивной формой взаимодействия при обучении. Вопервых, сами обучающиеся чувствуют себя комфортно, во-вторых, повышается прочность понимания и запоминания материала, в-третьих, возрастает требовательность к себе, самоконтроль, и наконец, у самого преподавателя есть возможность уделить внимание каждому.

В поисках потенциальных мест для бесплатных юридических курсов, я обратилась в Центр правовой и деловой информации на базе Нерюнгринской городской библиотеки и в Нерюнгринский филиал Алданского политехнического техникума. Оба учреждения дали согласие на проведение бесплатных юридических курсов. Таким образом, если программа заработает, в городе Нерюнгри есть как минимум две потенциальных территории.

Для обучения населения необходимо будет привлечь специалистов из разных отраслей права - адвокатов, приставов, представителей ЖКХ и др. И здесь возникает вопрос о финансировании. Если юридические курсы бесплатные, то кто будет платить преподавателям? Действие Постановления «Об утверждении перечня муниципальных программ муниципального образования «Нерюнгринский район» не продлили из-за недостатка бюджетных средств.

Поэтому, на основании Федерального закона от 06.10.2003г №131-Ф3 «Об общих принципах организации местного самоуправления в Российской Федерации» программу можно реализовать на добровольных началах в Алданском политехническом техникуме. Преподавать будут педагоги, привлеченные специалисты, а также сами студенты. В данном учебном заведении обучают по таким юридическим специальностям, как «Право и организация социального обеспечения» и «Правоохранительная деятельность». Поэтому учащиеся техникума уже на 2 курсе смогут проводить курсы совместно с педагогами - в виде практики. Помимо этого, в стенах Алданского техникума тоже можно проводить бесплатные юридические консультации, а Центр правовой и деловой информации привлечь в качестве партнера. Обмен правовыми ресурсами, взаимная реклама и совместное проведение мероприятий, направленных на повышение юридической грамотности населения

\footnotetext{
${ }^{4}$ Социальная педагогика: Курс лекций: Учебное пособие для студентов высших учебных заведений / Под общей редакцией. М.А. Галагузовой. - М.: ВЛАДОС, 2001. - 380 с
} 
Нерюнргринского района - все это можно реализовать совместно и на добровольных началах.

Чтобы доказать необходимость бесплатных юридических курсов для жителей Нерюнгринского района, я проанализировала действующие программы, направленные на повышение правовой грамотности, провела опрос, чтобы выявить актуальность курсов, продумала потенциальные темы и рассмотрела возможные места проведения курсов.

В результате написания данной работы была достигнута основная цель - создана программа бесплатных юридических курсов для людей, желающих повысить личную правовую грамотность. Сделаны следующие выводы:

1. Более $70 \%$ опрошенных обращались к юристам по таким вопросам, как: страхование, исковое заявление в суд, трудовые споры, переоформление недвижимости, заключение договора, наследство. Опрос показал, что жители Нерюнгринского района заинтересованы в повышении личной правовой грамотности, и нуждаются в бесплатных юридических курсах

2. Нерюнгринская районная администрация несколько лет проводила различные мероприятия, направленные на рост юридической грамотности населения. На базе Нерюнгринской городской библиотеки работает Центр правовой и деловой информации, который тоже занимается просвещением жителей Нерюнгринского района в этой сфере. Подобные программы действительно способствуют росту правовой культуры в Нерюнгринском районе.

3. Исходя из интересов опрошенных, были определены потенциальные темы для юридических курсов. Это правильное заполнение документов, изучение и подписание договоров, типичные уловки мошенников, вопросы ЖКХ. Данный перечень можно дополнять другими, актуальными для жителей Нерюнгринского района, вопросами.

4. Курсы лучше проводить в небольших группах по 5-7 человек. Исследователи считают, что малая группа способствует улучшению запоминания материала, повышает самоконтроль, и позволяет преподавателю уделить внимание каждому обучающемуся. Согласие на проведение бесплатных юридических курсов на своей территории дали два учреждения: Нерюнгринская городская библиотека и филиал Алданского политехнического техникума.

На основании Федерального закона от 06.10.2003г №131-Ф3 «Об общих принципах организации местного самоуправления в Российской Федерации» программу можно реализовать на добровольных началах в Алданском политехническом техникуме. Преподавать будут педагоги, привлеченные специалисты, а также сами студенты в качестве практики. Помимо этого, в стенах техникума можно проводить бесплатные юридические консультации, а Центр правовой и деловой информации привлечь как партнера.

\section{Список литературы}

1. Индустрия Севера. Новостной материал: «Опять мошенники» [Электронный pecypc] .- URL: http://www.indsever.ru/?module=articles\&action=view\&id=4102

2. Информационный сайт г. Нерюнгри. Новостной материал: «В г. Нерюнгри женщина попалась на уловку телефонных мошенников» [Электронный ресурc] URL: http://nerungri.ru/news/orgs/16810

3. Национальная педагогическая энциклопедия [Электронный ресурс] URL: http://didacts.ru/termin/yuridicheskaja-gramotnost.html 
4. Социальная педагогика: Курс лекций: Учебное пособие для студентов высших учебных заведений / Под общей редакцией. М.А. Галагузовой. - М.: ВЛАДОС, 2001. $380 \mathrm{c}$

\section{Анализ основных направлений энергосбережения предприятия ООО «Сибирь Техник»}

Киселёва Е.В., студент, Новосибирский государственный технический университет, 2. Новосибирск E-mail: kiskat22@mail.ru

Научный руководитель: к.т.н., доцент Путилова Н.Н.

Техническая служба с цехом оперативного обслуживания была образована в аэропорту «Толмачево» в 1957г. С 2016 г. «Сибирь Техник» отделилось от аэропорта, и образовало отдельное Общество с ограниченной ответственностью «Сибирь Техник».

- Основными направлениями деятельности Общества являются:

- Оперативное и периодическое техническое обслуживание ВС зарубежного производства;

производства;

- Инженерное сопровождение и планирование ТО ВС зарубежного

- Обслуживание и ремонт компонентов ВС зарубежного производства;

- Неразрушающий контроль конструкций и компонентов ВС зарубежного производства;

Была проведена характеристика персонала. Которая показала, что общая численность составляет 501 человек, из них работников с высшим образованием составляет больше половины общей численности, а конкретно 250 человек. Большей частью персонала являются мужчины, а средний возраст работников составляет около 40 лет.

С июня 2016 года «Сибирь Техник» отделился от Аэропорта Толмачево. На настоящий момент основными задачами, являющимися актуальными для Общества в связи с его отделением являются:

Развитие и становление службы энергоснабжения.

Пересмотр систем коммерческого учета.

Создание энергопаспорта.

Унификация договорных отношений по энергоснабжению.

Планирование и реализация мероприятий по энергоэффективности.

Проводя анализ особенностей энергоснабжения ООО «Сибирь Техник» в связи с изменением его статуса, следует отметить, что до июня 2016 общество было зависимо от аэропорта Толмачево, а с 2016 года отделилось и стало существовать как отдельное общество.

Так как Общество «Сибирь Техник» раньше было дочерним филиалом Аэропорта «Толмачево», то договор на электрообеспечение был заключен с аэропортом, а тот в свою очередь являлся перепродавцом электроэнергии. В связи с 